\title{
Lexicography in Gabon: A Survey
}

\section{B. Nyangone Assam and P.A. Mavoungou, Department of Afrikaans and Dutch, University of Stellenbosch, Stellenbosch, Republic of South Africa}

\begin{abstract}
This paper traces the historical development of lexicography in Gabon. Gabon, like most African countries, is multilingual. The recent inventories of languages spoken in Gabon are those established by Jacquot (1978) and Kwenzi-Mikala (1998). According to Kwenzi-Mikala (1997), there are 62 speech forms divided into 10 language groups or language-units in Gabon. These speech forms co-exist with French, the official language. In fact, in article 2 of paragraph 8 of the revised Constitution of 1994 the following can be read: "The Gabonese Republic adopts French as the official language. Furthermore, she endeavours to protect and promote the national languages." This constitutional arrangernent naturally makes French the language used in education, administration and the media.

The survey of lexicography in Gabon that is presented here includes the linguistic situation in and the language policy of Gabon, the lexicographic survey itself, as well as the lexicographic needs of the different speech forms (including languages and dialects). Initially, the pioneers of Gabonese lexicography were missionaries or colonial administrators. Very little was done in this field by the Gabonese themselves. Although credit is to be given to these early works, there are a number of shortcomings regarding the linguistic as well as the metalexicographic contents of dictionaries and lexicons produced during this period. In fact, the main weak point of those studies was the lack of tones in the written transcription of oral productions and orthographic problems. Furthermore, in those contributions, the theory of lexicography is largely unknown and lexicographic works are hardly ever based on authentic data corpora of the languages being described.
\end{abstract}

Keywords: SPEECH FORMS, LANGUAGE GROUP(S), OFFICIAL LANGUAGE, LANGUAGE POLICY, LEXICOGRAPHIC NEEDS, LEXICOGRAPHIC WORKS, DICTIONARY BASE, METALEXICOGRAPHY, LEXICOGRAPHIC TRAINING.

Abstrait: Lexicographie au Gabon: Un état des lieux. Le present article retrace l'histoire de la discipline lexicographique au Gabon. Comme la plupart des pays africains, le Gabon est un état multilingue. Les classifications établient par Jacquot (1978) et Kwenzi-Mikala (1998) sont souvent citées comme les travaux d'inventaire les plus récents sur les parlers gabonais. Selon Kwenzi-Mikala (1997), le Gabon compte 62 parlers reparties en 10 unités-langues. Les dits parlers cohabitent avec le français qui faut-il le rappeler jouit d'un statut particulier. En effet, à l'article 2 du paragraphe 8 de la Loi fondamentale révisée de 1994, on peut lire ceci: «La République gabonaise adopte le français comme langue officielle. En outre, elle s'engage à protéger et à promovoir les langues nationales». Cette disposition constitutionnelle fait natureltement du français le véhicule et la matière de l'instruction, la langue de l'administration et celle des médias.

L'état des lieux de la lexicographie au Gabon présenté ici prend en compte la situation et la politique linguistique au Gabon, l'état des connaissances lexicographiques à proprement parler ainsi que les besions lexicographiques des differents parlers au regard de ce qui existe déjà. Les 
premiers travaux a caractère lexicographique ont été réalisés essentiellement par les missionnaires et les administrateurs coloniaux. Très peu de gabonais étaient engagés dans la confection des dictionnaires et lexiques à cette époque pionnière. Enfin, il convient de souligner que le principal talon d'Achille de ces travaux de la première heure est à la fois linguistique et métalexicographique. En effet, la majorité de ces travaux ne prennent pas en compte le système tonal des parlers décrits et s'inscrivent rarement dans un cadre théorique défiri. Enfin, ils souffrent de nombreuses insuffisances orthographiques et sont rarement basés sur des corpus linguistiques.

Mots-clefs: PARLERS, UNTTÉ(S)-LANGUE(S), LANGUE OFPICIELLE, POLTTIQUE LINGUISTIQUE, BESOINS LEXICOGRAPHIQUES, TRAVAUX LEXICOGRAPHIQUES, BASE DU DICTIONNAIRE, METALEXICOGRAPHIE, FORMATION LEXICOGRAPHIQUE.

\section{Introduction}

The survey of lexicography in Gabon presented here has a twofold objective:

to give an account of lexicographic works and studies in Gabon, and

to envisage the different lexicographic needs of the Gabonese languages.

However, before discussing lexicographic studies and the lexicographic needs, it is necessary to offer an explanation of the linguistic situation in and the language policy of Gabon.

An overview of the development of lexicography shows that there are imbalances between languages. Some are far more advanced than others. Therefore, the treatment of each group will vary in length according to the lexicographic data available.

\section{Linguistic situation in Gabon}

Like the majority of other African countries, Gabon is a multilingual country. It is, therefore, necessary to distinguish between multilingual states: those which have several or more dominant languages and those without dominant languages, except regionally. Gabon belongs to the latter group.

As far as classification is concerned, many studies exist on the Gabonese languages.

The inventories of Jacquot (1978) and Kwenzi-Mikala (1998 and 1998b) are regarded as the most recent classifications of the Gabonese languages. Jacquot's classification updates Guthrie's (1953) listing. It is a genetic or genealogical inventory. However, the classification proposed by Kwenzi-Mikala is geographical-administrative. Kwenzi-Mikala (1988: 57) initially grouped the 62 heritage speech forms ("parlers", including languages and dialects) in 8 language groups (a group of different speech forms that are mutually comprehensible) and thereafter (Kwenzi-Mikala 1998) in 10 language groups. In order to 
establish these language groups or language units, Kwenzi-Mikala used the criteria of mutual intelligibility (also referred to as intercomprehension) and the opening greeting formality "I say that" (cf. Emejulu and Nzang-Bie 1999: 2). This classification ${ }^{2}$ is as follows:

- the Mazuna group: Fan-Atsi, Fan-Make Fan-Mvai, Fan-Ntumu, FanNzaman and Fan-Okak;

the Myene group: Enenga, Ghalwa, Mpongwe №mi, Orungu and Okoa;

- the Mekana-Menaa group: Akele, Ungom, Lisighu, Mbanwe, Metombolo, Seki, Tumbidi, Shake, Wumpfu and Lendambomo;

- the Mekona-Mangote group: Ikota, Benga, Shamayi, Mahongwe,

- Ndasha, and Bakola;

- the Membe (or Okande-Tsogho) group: Ghetsogho, Ghepinzi, Kande, Ghevhovhe, Ghehimbaka, Ghevhiya, Ebongwe and Kota-kota;

- the Merye group: Ghisira, Ghivharama, Ghivhungu, Yipunu, Yilumbu, Yisangu, Ngubi, Civili, Yirimba and Yighama;

- the Metye group: Yinzebi; Yitsengi, Yimwele, Yivhili, Liduma, Liwanzi and Yibongo;

- the Membere group: Lembaama, Lekanini, Lindumu, Lateghe and Latsitseghe;

- the Mekana group: Bekwil, Shiwa (or Makina) and Mwesa;

- the Baka group: Baka.

Some criticism has been directed at this classification based on the sociolinguistic criteria of intercomprehension. Earlier, Hombert (1990: 30) asked himself: "S'agit-il d'une intercompréhension totale et immédiate? ou doit-on considérer qu'il y a encore intercompréhension si le locuteur d'un parler $\mathrm{A}$ a besoin d'une période d'adaptation (de quelques jours? de quelques semaines?) pour comprendre l'essentiel (la totalité?) des conversations des locuteurs d'un parler B?" More recently, Emejulu and Nzang-Bie (1999: 2) stated that "the intercomprehension criterion used confounds some crucial sociolinguistic historicity and does not systematically reflect the native speakers' linguistic intuition". Despite the shortcomings expressed above, Kwenzi-Mikala's classification serves as a useful source of reference for scientific works for two reasons. Firstly, it offers a solution to the problem of the enumeration of all the heritage speech forms of Gabon. After Johnston (1922: 138-144), Guthrie (1953: 55-73), Doke and Cole (1963: 63-76) and Jacquot (1978), Kwenzi-Mikala (1998) introduced a grouping of those speech forms in 10 language-units. Secondly, it is established according to a comparative underlying design. Other speech forms are still to be identified, especially those which are threatened with extinction.

As far as dialectology is concerned, Fan and Omyene are the sole Gabonese languages of which the dialectal status is more or less clearly established, having six dialects each. For the other Gabonese speech forms, dialectal 
differences are still to be identified and mapped. This is the difficult task that is currently being carried out by the researchers of the Laboratoire de phonétique et linguistique africaine of the Université Lyon 2 under the supervision of Prof. Jean-Marie Hombert using the framework of the Atlas Linguistique du Gabon $(A L G A B)$. The conclusion of this project will provide a clear picture of the language and dialect boundaries in Gabon.

\section{Language policy of Gabon}

According to Kwenzi-Mikala (1990: 123), the language policy of Gabon largely depends on the one inherited from the colonial era. In fact, in the revised constitution it is stipulated: "The Gabonese Republic adopts French as the official language. Furthermore, she endeavours to protect and promote the national languages" (1994, article 2, paragraph 8). With this official status, French serves as the sole medium of instruction in the national educational system, and as the language of business, in civil administration and the media.

For several years Gabonese languages have been sidelined. When the Government became aware of the importance of the national languages in the development of the country, it started to promote them. A seminar Les Etats généraux de l'Éducation et de la Formation was convened from 12 to 23 December 1983 in this regard. One of the recommendations of the workshop was the introduction of the Gabonese languages in the national educational system. However, no concrete policy ensued from this recommendation. Fourteen years later, this recommendation was stressed again during the Table ronde sur les Recherches linguistiques et l'Enseignement des Langues au Gabon that was held from 9 to 11 December 1997.

Recently, in April 1999, the Séminaire sur la Standardisation de l'Orthographe des Langues gabonaises was organised by the Ministry of National Education in Libreville.

National languages are used as a medium in the literacy program for adults and in broadcasting. The introduction of a postgraduate course at the Normal sup (College of Education) to train teachers of Gabonese languages during the academic year 1998-1999 is an indication that the educational system of the country is undergoing drastic changes. All the concrete actions that the Government has undertaken toward the development of the national languages will sooner or later allow the production of teaching materials enabling them to be used both as medium and subject of instruction in schools.

As far as lexicography is concerned, the Séminaire sur la Lexicographie Bantu held at CICIBA (Centre Internationale des Civilisations Bantu) in Libreville is an indication of some of the recent developments in this field. This seminar took place in 1997, and was attended by delegates from six African countries. During the seminar Dr D.J. van Schalkwyk, editor-in-chief and Dr F.J. Lombard, senior coeditor of the Woordeboek van die Afrikaanse Taal (WAT), presented lexicographic training. Particular attention was paid to the 
planning and management of lexicographic units as well as to practical aspects of lexicography (cf. Bureau of the WAT 1997-1998).

\section{Survey of lexicography in Gabon}

The survey of lexicographic works and studies in Gabon will be done according to the 10 language groups of Kwenzi-Mikala (1998a). ${ }^{3}$

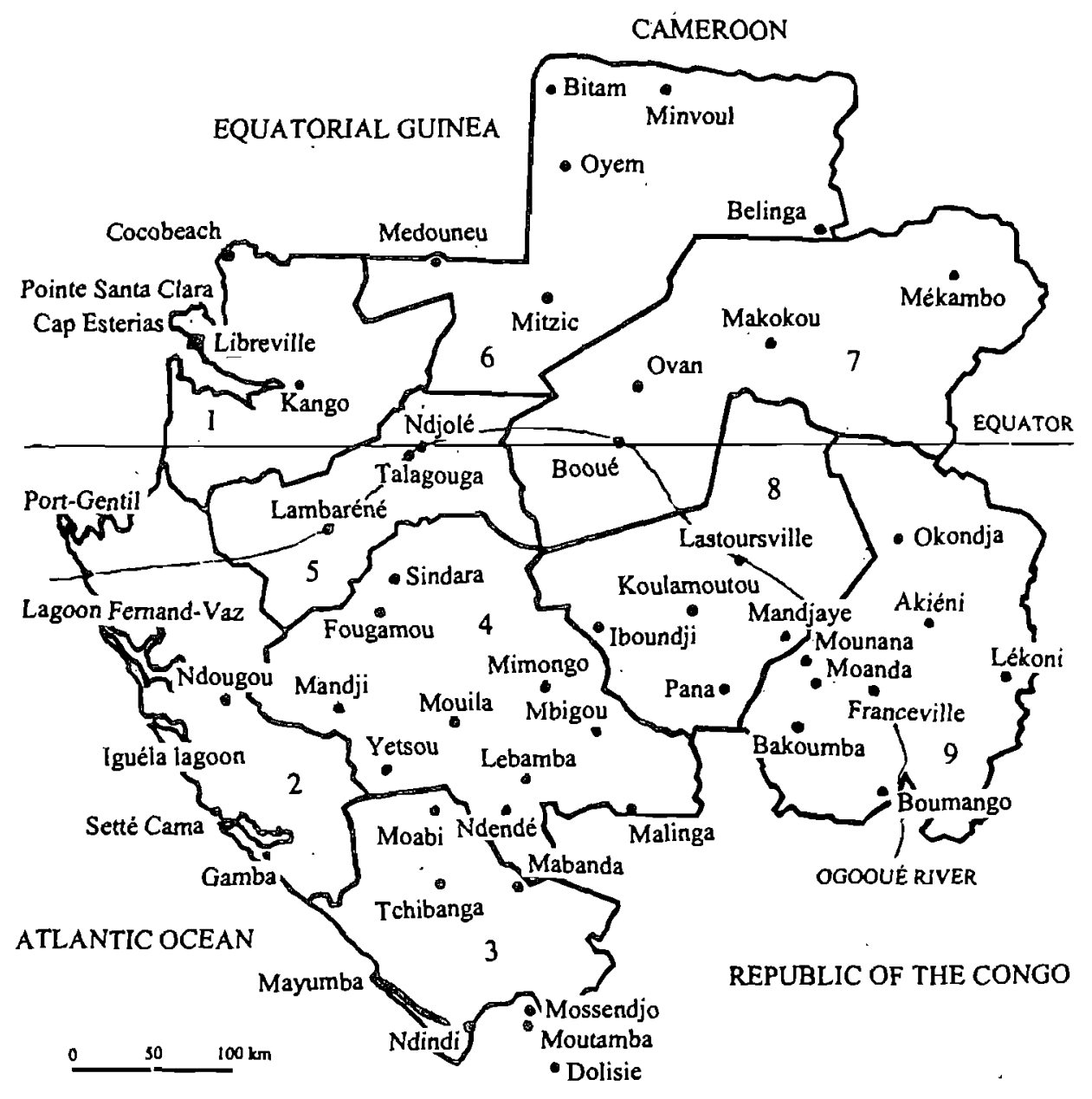

1 Estuaire

2 Ogooué-Maritime

3 Nyanga
4 Ngounié

5 Moyen-Ogooué

6 Woleu-Ntem
7 Ogooué-Ivindo

8 Ogooué-Lolo

9 Haut-Ogooué 


\subsection{Mazuna lexicography.}

Fan is the home language of 29 percent of the population (circa 427000 people).

The speech forms of this group are mostly found in four of the nine provinces of Gabon, namely Estuaire, Moyen-Ogooué, Ogooué-Ivindo and WoleuNtem. Fan-Atsi is spoken in Ndjolé and Lambaréné; Fañ-make in Libreville and Kango. Fan-Mvaï is found in Minvoul; Fan-Ntumu in Oyem and Bitam. Finally, Fan-Nzaman and Fan-Okak are spoken in the regions of Makokou-Ovan-Booué and Medouneu-Cocobeach-Mitzic respectively. Fan is a so-called cross-border language because it is also spoken in neighbouring countries, namely in Equatorial Guinea, Cameroon, Săo Tomé and the Republic of the Congo.

Mazuna lexicography starts with the publication of the bilingual Dictionnaire fang-français by R.P. Marling (1872). This lexicographic work is followed some years later by another bilingual dictionary, the Dictionnaire français-fang by R.P. Lejeune (1892). The work consists of 347 pages and has two sections. The first section contains an overview of Fan grammar; the second part is the dictionary itself. Important is the publication of the Encyclopédie pahouine by Largeau (1901), a colonial administrator. With its \pm 4996 articles covering 699 pages, the book is the only encyclopaedia ever compiled in a Gabonese language. It is divided into two parts.

The first part is a cultural overview of the Fan people. Here the compiler does not only renew the question of the origin of the Bafan (speakers of Fan), but other anthropological issues regarding rituals, the value system and mythology are discussed extensively.

The second part, which contains the encyclopaedia itself, starts with a lexicological or lexicographic chapter (as it is called by the compiler). This chapter contains the user's guidelines and the minigrammar of the encyclopaedia. It provides the user with a relevant discussion on the pronunciation system, the orthography and the punctuation system used as well as some morphological information such as the parts of speech, word formation and the conjugation system of Fan that is abundantly illustrated by tables. Although credit is to be given to this work, it reveals a number of shortcomings. The writing system proposed by the compiler is very much along the lines of the orthographic traditions of French. However, there is a big difference between the sound systems of the African languages and those of the European languages. As a result, the transcriptions proposed are likely to be only approximate. Moreover, the grammatical content is somewhat outdated. These shortcomings can be remedied by taking note of some of the recent works on Fan grammar, namely those of Mba-Nkoghe (1981), Andeme Allogho (1980), Mba-Nzue (1981) and Ondo-Mebiame (1992) on Fan-Atsi, Fan-Nzaman, Fan-Mvaï and Fan-Ntumu respectively. As far as the lexicographic section is concerned, the entries of the encyclopaedia are arranged in alphabetical order. They vary in length from short explanations of terms and concepts to a more comprehensive treatment of lexical items. Cross-references guide the reader to thematically related articles. 
In the preface of the book it is clearly stated that the encyclopaedia is based on the dialects Make and Atsi. However, the compiler does not mention either the primary or the secondary sources of his macrostructural elements. The encyclopaedia itself contains lexicographic data such as the lemma in French, the translation equivalent in Fan, some contextual information, and indication of the plural.

According to Largeau (1901: 4) the value of the encyclopaedia lies in the fact that it can be used as a useful reference work by scholars from various fields, among others politics, philosophy, economics and ethnology.

The most important Fan dictionary is that of the Genevan pastor Samuel Galley entitled Dictionnaire fang-français et français-fang, edited by Henri Messeiller and published in Paris in 1964. Like its predecessors, this work is a bilingual dictionary. It consists of \pm 13925 articles covering 588 pages. It is the result of the input from the Société des Missions Évangéliques de Paris in Gabon through its station Talagouga in the region of Ndjolé. After 40 years in Gabon, Galley passed away in 1959 without having the opportunity to see his major work being published. The Fan people are indebted to the Association française des Amis d'Albert Schweitzer for the publication of the Galley dictionary. It is based on the translation of the Bible in Fan, another tremendous task that Galley undertook for the Fan community of Talagouga. In contrast with earlier dictionaries such as the works by Marling (1872) and Lejeune (1892), the Galley dictionary is intended to meet the needs of both Fan and French speakers because of its bidirectional nature. As far as the macrostructure is concerned, the lemmata are arranged alphabetically. The microstructure includes a lot of data, e.g. the parts of speech, class numbers, translation equivalents, meaning explanations as well as cross-references. Compare the article of the lemma abîñya:

ABÎÑYA (h) n. 4, pl. mebiñya. Rameau vert, bout de branche avec feuilles vertes. On s'en sert pour fermer les barrages pour pêcher (lôkh h, pêcher). En faisant un paquet enveloppé d'écorces et en y mettant le feu, on obtient une épaisse fumée pour étourdir les abeilles et prendre le miel dans la ruche. Syn.: ébî h).

Another feature of the dictionary worth mentioning concerns the access structure: the use of typographical markers such as the presentation of the lemmata in bold small capitals as well as the running heads of the column which form the outer rapid access structure (Hausmann and Wiegand 1989: 329) make it easier for users to find the word for which they are looking. Apart from his lexicographic and evangelical activities, Pastor Samuel Galley was also involved in the production of didactic materials. His best-known teaching aid is the book Nteni osu nteni Fañwe, published in 1889 under the aegis of the Protestant station of Talagouga. The following is Mayer's (1990: 74) comment on the book: "(C'est) un opuscule de 14 pages centenaire! 'Premier livre de fang' dit le 
titre. C'est la mission protestante de Talagouga (près de Ndjolé) qui est à l'origine de cette publication dont la reliure est assurée par du fil à aiguille. Étrange illustration de couverture: minarets et chéchias composent un paysage sans doute exotique mais fantastiquement irréaliste."

The last work to be treated was compiled by Martrou (1924), a missionary of the Congrégation des Pères du Saint-Esprit. It is the bilingual Lexique fannfrançais consisting of 3431 articles covering 137 pages. It is divided into two parts. Part I presents the outline of Fan grammar, while part II deals with the lexicon itself. The lexicon contains lemmata in Fan and French translation equivalents. The use of typographical markers such as the printing of the lemmata in bold capitals, as well as the running heads, have relatively improved the access structure of the lexicon. The orthography employed in the lexicon is based on the principles expounded by $\mathrm{Ch}$. Sacleux in his book Essai Phonétique. The fact that the work contains information on stress in the lemmata shows the lexicographer's awareness of the necessity to give an account of the pronunciation of the language. According to Martrou, tonic accent in Fan is characterised by a global rise and the lengthening of the syllable. It is indicated by the stress mark (').

In conclusion, all the dictionaries available for Fan language are translating dictionaries and biased towards French. Furthermore, they reveal a number of shortcomings that need to be remedied. Most of these works do not mark tone or give the pronunciation of the language. To a greater or lesser degree, the earlier dictionaries lack a metalexicographic foundation, but as far as these shortcomings are concerned, they are excusable if one considers that the compilers of these earlier works were neither linguists, nor trained lexicographers. The most important and most often stated shortcoming is that these dictionaries contain a lot of orthographic inconsistencies. For example, P. Alexandre (1961, as quoted by Kidda Awak 1990: 11) points out that the Fan language has acquired "trois transcriptions [catholiques] et deux [protestants] pour environ un million de locuteurs, sans parler des différences morphologiques dues à des calques catholiques sur l'allemand, le français et l'espagnol, et protestants, sur l'américain".

To a greater or lesser degree, these shortcomings also apply to the language group that is treated in the following section.

\subsection{Myene lexicography}

Omyene ${ }^{4}$ is the home language of 5 percent of the Gabonese population.

The speech forms of this language group are mainly found in three provinces of Gabon, namely Estuaire, Moyen-Ogooué and Ogooué-Maritime. Enenga is spoken northeast of Lambaréné, in the vicinity of lake Zile. Ghalwa is found around lakes Onangué, Avanga and Ezanga, and on the island of Lambaréné. Mpongwe is spoken in Libreville as well as on the island of Pointe- 
Dénis. Finally, Nkomi is in use southeast of Port-Gentil and around the lagoon Fernand-Vaz.

The first dictionary to be compiled in Myene is the Dictionnaire françaismpongwe by R.P. Amable Delorme (1877). The dictionary covers 354 pages and was published under the auspices of the Missionnaires de la Congrégation du Saint-Esprit et du Saint-coeur de Marie. Lemmata are given in French and supplied with a Mpongwe translation equivalent as well as some examples. Except for suprasegmental and orthographic problems, the monodirectional feature of the work is the main weak point of the dictionary, that could only be used actively by speakers of French but passively by those of the Mpongwe dialect. This relation between active and passive language use is reversed in Gachon's Dictionnaire mpongwè-français published in 1881 . The book covers 287 pages and consists of two sections. The first section presents Mpongwe grammar, while the second section contains the dictionary itself. Lemmata are arranged alphabetically and according to the word tradition. The dictionary has been a great contribution to Gachon's translation of the Bible Gnango ine agamba mi re tendo pa gou'ejango j'agnambie ji felio né TESTAMAN NOUNGOU NI TESTAMAN GNONA gou 'inongo gni mpongoue published in 1891. The dictionary was republished in 1974.

The last contribution is Raponda-Walker's dictionary. It was published for the first time by the Imprimerie de la Libre Lorraine in Metz (1930-1934). It is monodirectional, with Mpongwe as source and French as target language. In 1961, 27 years later, the dictionary was published in the reverse direction French-Mpongwe by the Imprimerie Saint Paul in Brazzaville. This version of the dictionary has since been reprinted under the auspices of the RapondaWalker ${ }^{5}$ foundation in 1995. The last version of the work comprises some 8000 articles arranged alphabetically according to the full word tradition. The first part of the book is the dictionary itself, while the back matter or the second part of the dictionary contains an exposition of Mpongwe grammar. The dictionary articles include the following data categories: the lemma in French, the part of speech, a label, the Mpongwe translation equivalent, some examples as well as the use of typographical indicators. Compare the following example from this dictionary:

Communiquer V.A. (transmettre) nóza; pa. Communiquer une lettre, une maladie, nóz'ezango ; nóze nkani. Communiquer un ordre, bol'okenge. (Correspondre). Communiquer par lettre, tendane yango; une nouvelle, myeze ntsango. (Aboutir) punda, pókósa. Le Fernand-Vaz communique avec l'Océan, Eliwe-Nkómi zi punda go ntsuwa. Ce chemin communique avec la plaine, mpónó yinó yi pókósa g'orove. Se communiquer, nógana. Le pian se communique, abukwè mi nógana.

As far as the primary source of the dictionary is concerned, Raponda-Walker's work is based on examples of oral usage of Mpongwe which was collected over 
many years from various sources. Earlier books on Mpongwe literature (especially dictionaries and the Bible), as well as some of the monolingual and bilingual dictionaries of French published during the period concerned, are most probably the secondary sources of the work. The compiler based the orthography used in the dictionary upon the set of symbols presented by himself (Raponda-Walker 1932). This alphabet is much along the lines of the Practical Orthography of African Languages published in 1928 by the International African Institute (see also Touré (1990: 56-57) and Kwenzi-Mikala (1998a: 219-220) for reviews on this matter).

From the foregoing exposition, it is clear that all the dictionaries available on the Omyene language have a common denominator: they are all translation dictionaries based on the Mpongwe dialect and were compiled by Catholic missionaries.

The next language group to be examined is less developed.

\subsection{Mekana-Menaa lexicography}

The speech forms of this language group are scattered in six provinces of Gabon, namely Estuaire, Haut-Ogooué, Moyen-Ogooué, Ngounié, OgoouéLolo and Ogooué-Ivindo. Nkele is spoken in Lambaréné and Sindara, Ungom north of Franceville, in Koulamoutou and around Mékambo. Lisighu and Metombolo are spoken in Lastoursville and Seki in Cocobeach. Shake is found in Booué and Lastoursville, and Tumbidi in Mbigou and Malinga. Lendambomo is spoken in Booué, Okondja as well as south of Mékambo. Finally, Wumpfu is found in Mbigou, Malinga and north of Franceville.

Except for word-lists at the end of linguistic works in this language group, nothing exists as far as lexicography is concerned.

\subsection{Mekona-Mangote lexicography}

The speech forms of this language group are dispersed in five of the nine provinces of Gabon, namely Estuaire, Haut-Ogooué, Ngounié, Ogooué-Lolo and Ogooué-Ivindo. Ikota is spoken in Booué and Mékambo, Benga north of Libreville at Cap Esterias and Pointe Santa-Clara. Shamayi is found in Makokou and Okondja, Mahongwe and Bakola in Makokou. Finally, Ndasha is spoken in Mbigou, Mandjaye and Okondja. Moreover, the Bandasha are also localised in the Republic of the Congo, more precisely in Mossendjo and in Dolisie and in the region of Nyari in the commune of Moutamba.

At present, there exists only one lexicographic work in this group, namely Lexique français-ikota by R.P. Perron (1964), published under the auspices of the Mission Catholique de Makokou. An interesting fact is related to the primary sources of the work. The lexicon is based on the manuscript notes of R.P. Lamour. The articles are arranged in alphabetical order. They start with a French 
lemma followed by a translation equivalent in Ikota, and some examples.

The language group which follows, is far more developed.

\subsection{Membe lexicography}

The speech forms of this group are mostly found in three of the nine provinces of Gabon, namely Ngounié, Ogooué-Ivindo and Ogooué-Lolo. Ghetsogho is spoken in Mouila, Moabi and Sindara. Ghepinzi and Ghevhiya are found in Mouila and Ghevhovhe in Koulamoutou. Ghehimbaka, Ebongwe and Kotakota are mostly found in Booué and Mimongo.

All the works available in Membe's literature touch the domains of linguistics and religion. These works, which contain a lot of information regarding the lexicon as well as the grammar of the speech forms of this group, can be used as a starting point for the compilation of new dictionaries. Studies that have dealt specifically with lexicographic issues in this language group include work by the following authors: Raponda-Walker (s.a.) and Bodinga-bwa-Bodinga and Van der Veen (1990). Raponda-Walker's contribution is a bilingual dictionary entitled Dictionnaire getsogo-français. The work contains more than 5000 articles covering 237 pages. Lemmata in Ghetsogho are supplied with French translation equivalents as well as some examples. The author also compiled a reverse edition with French as source and Ghetsogho as target language. Bodinga-bwa-Bodinga and Van der Veen's paper "Plantes utiles des Evia" deals with plant names as well as their medicinal qualities. The work is much along the lines of the Plantes utiles $d u$ Gabon published in 1961 by Raponda-Walker and Sillans and contains some 608 Ghevhiya terms. The entries of the lexicon appear in three columns. The scientific names of the plants are given in the first column in alphabetical order. The Ghevhiya names appear in the second column. The last column deals with the therapeutic properties of the plants listed. This is illustrated by the following example:

Abrus precatorius dì-ndende Propriétés adoucissantes (feuilles), soins de la voix (chanteurs)

Unfortunately, the authors propose no metalexicographic discussion on how these plant names should be treated in a dictionary of plant names for example. Finally, the collaboration of Bodinga-bwa-Bodinga and Van der Veen also includes the compilation of a bilingual dictionary: Dictionnaire gevia-français (in preparation).

\subsection{Merye lexicography}

The speech forms of this group are mostly found in four of the nine provinces of Gabon, namely Ngounié, Nyanga, Ogooué-Maritime and Ogooué-Lolo. 
Ghisira is spoken in the regions of Fougamou, Mandji and Ndougou; Ghivharama in Setté Cama and Gamba. Ghivhungu is found in Mandji, Yetsou and Moabi. Yipunu is spoken in Mouila, Tchibanga, Ndendé, Mabanda and Moabi. Yilumbu is mainly spoken in Mayumba, Gamba and Setté Cama. Yisangu is found in the regions of Mimongo and Mbigou, and from Koulamoutou to Iboundji. Ngubi is spoken around the Iguéla lagoon, Civili in Mayumba and Ndindi, and Yirimba in Moabi. Yighama is found between Mayumba and Tchibanga. Some speech forms in this group are so-called crossborder languages, namely Yipunu, Yilumbu (also spoken in the Republic of the Congo and the Democratic Republic of the Congo) and Civili (also spoken in the Republic of the Congo and Cabinda in Angola).

The first lexicographic work that has to be mentioned in this group is the Dictionnaire français-vili by R.P. Marichelle (1900). The dictionary which covers 114 pages was published in Loango. It comprises a brief outline of the Civili speech form. The dictionary articles supply the following lexicographic data: a treatment unit in French, a Civili translation equivalent as well as some examples.

The next work published was the Grammaire pounoue et lexique pounouefrançais by Bonneau (1956). The work which covers 177 pages, contains two sections. The first section presents Yipunu grammar, while the second section contains the lexicon itself. The entries are arranged alphabetically. They provide the reader with lemmata in Yipunu as well as translation equivalents in French. As far as the primary sources are concerned, Bonneau's work is based upon a series of papers that the author wrote from 1940 to 1952 in the Journal de la Sociêté des Africanistes. A more recent article "Lexique" by Rittaud-Hutinet (1980) is very interesting with regard to the lexicographic contents. As far as the primary sources are concerned, the lexicon was initially compiled on the basis of a questionnaire of Joseph $\mathrm{H}$. Greenberg. Then it was enlarged from other sources. The work contains a comprehensive introduction in which the compiler deals with issues regarding semantics (synonymy, antonymy, homonymy and figurative speech) and morphology (gender, concord and derivation) as well as the tonal system of the speech form. Another good feature of the work is that the lexicographer gives an account of the principle or method of arrangement according to which all the lexical items have been entered in the lexicon. Entries are presented in three columns. In the first column, Yipunu lemmata are given alphabetically under the initial letter of the stem of each word. The treatment units are accompanied by an indication of the class number and eventually by a label or usage marker. The second column contains translation equivalents as well as meaning explanations. The last column deals with semantic and morphological information such as synonyms, metaphors, compounds, etc. The following example illustrates the point in question:

-kanga 1/2 ami avec lequel on est en relation cf. -mba:tsi (C') $9 / 2=$ ami d'échanges et d'hospitalité 
The lexicon itself contains some 945 articles and is divided into two sections which reflect the different tonal patterns of Yipunu. In one section the substantives are represented according to the following tonal classes: $A, B, D, B / D, B^{\prime}$ and $B^{\prime} / C^{\prime}$ and in the other section the verbs are listed under the tonal classes $A$, $B$ and $A / B$.

As far as Yipunu is concerned, the work of Kwenzi-Mikala is indispensable. Some of his contributions deal with semantic issues, such as borrowing, componential analysis and anthroponymy, to list a few. For example, his paper "Contribution à l'analyse des emprunts nominaux du yipunu au français" is a phonological and semantic analysis of Yipunu loan words based on a corpus of 70 words borrowed from French by the Gabonese speakers of Yipunu. In "Analyse sémique des termes dénotant les relations parentales en yipunu", the author analyses the kinship system and terms of Yipunu according to the model developed by the French structuralists in the field of semantics which is largely influenced by B. Pottier and A.-J. Greimas, among others. He organises his description on the basis of the following semantic axis: axis of generations; axis of sex; axis defining the linear character; axis defining consanguinity; and finally the axis defining the direct and lateral characters of the relation on the father's side.

Finally, his article "L'anthroponymie chez les Bapunu du Sud-Gabon" of 1990 deals with anthroponymic issues. Particular attention is paid to the relation between the function of the personal name and the status of the bearer. Moreover, the author is currently working on a corpus of traditional personal names including all the Gabonese tribes. From ongoing research work, some unpublished contributions on the speech forms of this language-unit should be mentioned. The first unpublished work is the Lexique isangu-français compiled by Naidaillac (1992) and presented at the Université Lyon 2. The second contribution is Jean Blanchon's Yipunu dictionary in electronic form. It contains some 4272 lemmata with their Protobantu reconstructions.

\subsection{Metye lexicography}

The speech forms of this group are mostly found in four of the nine provinces of Gabon, namely Haut-Ogooué, Ngounié, Ogooué-Ivindo and Ogooué-Lolo.

Yinzebi is the most widely spread speech form of the group and it is located in regions such as Mbigou, Lebamba, Malinga, Lastoursville, Koulamoutou, Pana-Iboundji and Mounana-Bakoumba. Yitsengi is spoken in Lastoursville-Moanda-Bakoumba, and Yiwele in Mbigou. Yivhili is found in Booué-Sindara, and Liwanzi in Lastoursville-Moanda. Liduma is spoken in Lastoursville and Yibongo in Moabi.

The first work in Metye lexicography is the lexicon Vocabulaire françaisaduma; vocabulaire aduma-français by R.P. Dahin (1893). The author started with French lemmata and their translation equivalents in Liduma. Later, he reversed his macrostructural elements and started again, this time with Liduma lem- 
mata. This makes the lexicon useful for speakers of both French and Liduma. As far as the primary sources of the lexicon are concerned, it seems that R.P. Dahin based his work on the Catéchisme en langue adouma that he wrote in 1891, as well as other literary materials.

The next lexicographic work to be published has a restricted macrostructure. It is the pocket dictionary of Yinzebi entitled Petit dictionnaire bantou du Gabon: français-ndjabi; ndjabi-français compiled by Muroni (1989). Despite segmental as well as suprasegmental shortcomings, the quality of the dictionary lies in its bidirectional feature. Another Yinzebi dictionary is being compiled by Nadaillac in collaboration with the ALGAB's team.

Finally, the most important dictionary of this group is certainly the Dictionnaire ndumu-mbede-français by A. Biton and J. Adam (1969). Biton and Adam's work is interesting because it does not only involve French and one of the Gabonese heritage speech forms as it is the case in most of the existing dictionaries, but it involves French and two Gabonese speech forms (Liduma and Lateghe). The primary source of this multilingual dictionary are probably the Grammaire composée mbede-ndumu-duma which Adam published in 1954. However, this grammar book has to be regarded as only one of the various sources of the author. In fact, after 52 years in Gabon where he passed away in 1981, Adam's contribution to Gabonese oral literature encompasses many articles on the different speech forms of Haut-Ogooué province.

\subsection{Membere lexicography}

The speech forms of this group are mostly found in Haut-Ogooué province. Lembaama is spoken in the region Franceville-Okondja-Akiéni. Lekanini is found in Franceville and Boumango. Lateghe is spoken in Akiéni-Lékoni and Latsitseghe in Lékoni. Lindumu is used in Franceville.

Membere lexicography starts with the publication of the bilingual dictionary Dictionnaire français-ndumu et ndumu-français by R.P. Biton (1907). The work covers 97 pages and is divided into two parts. The first part introduces the reader to the grammar of Lindumu, while the second part contains the dictionary itself. The first section of the dictionary starts with French lemmata. Then, the compiler reverses the languages in the second section of the dictionary. The present dictionary has served as a basis for the production of religious didactic materials such as the Kategism Ndumu in 1962 and a few years later, in 1969, the Dictionnaire ndumu-mbede-français et français-ndumu-mbede compiled by Biton in collaboration with Adam. The characteristic feature of this dictionary is that it involves three languages (French, Lidumu (Ndumu) and Lateghe (Mbede)) and that the languages are reversed within one and the same dictionary. Furthermore, lemmata are excerpted from the lexical stock of the plant names of the region of Franceville. The next work to be examined is an interdialectal lexicon entitled "Vocabulaire comparé des principaux dialectes ayant cours en HautOgooué" published by Castex in 1938. The work is an interesting contribution 
to the field of dialectology (also called linguistic geography) and can be used as a valuable reference work for the compilation of a multilingual or pandialectal dictionary involving the different speech forms of the Membere group which presents a relative rich lexicographic insight in comparison to the last two groups of this survey, namely the Mekana and Baka language groups.

\subsection{Mekana lexicography}

The speech forms of this group are mostly found in the Ogooue-Ivindo province. Bekwil is spoken in Makokou and Shiwa (or Makina) in Booué. Mwesa is found in Mékambo.

As far as this group is concerned, a lot of work is still to be done. However, the contributions of Puech (1990), Yembi Bouka (1995) and KwenziMikala (1998a: 10-16) contain an outline of the grammar and the oral literature of Shiwa, Bekwel and Mwesa respectively. As far as lexicographic publications are concerned, nothing is available.

\subsection{Baka lexicography}

Baka is the sole speech form of this group which is spoken in Minvoul-Makokou-Belinga.

The available literature on this group includes the work of Mayer (1987) and Mayer and Voltz (1990) in the field of anthropology, among others. Lexicographic activities are still to be started.

\section{Lexicographic needs of the Gabonese languages}

The purpose of earlier dictionaries was basically to serve as reference works for European traders and French colonial administrators in their daily routine. Moreover, dictionaries have served as a source for the compilation of pedagogic or teaching materials, such as the translation of the Bible (for evangelisation purposes), grammar books and syllabi to teach the inhabitants to read and write.

As far as the lexicographic needs of Gabonese languages are concerned, there is a lack of dictionaries of various types as well as a lack of a dictionary culture. This does, of course, not mean that the lexicographic needs of Gabonese languages have to be derived from the full typological diversity of dictionaries available (cf. Gouws 1996: 100). Thus, there is a need for dictionaries aimed at a very specific target user. It is here that once again the comments of Gouws (1996: 100) can be recalled: "the first priority for any given language is to compile a dictionary belonging to a typological category already represented in that language but where the existing dictionary does not comply with the criteria set by the needs' analysis of the real users." 
As it clearly appears in the above survey, most dictionaries available for Gabonese languages are translation dictionaries and biased towards French. Moreover, they lack important linguistic features such as tones as well as a metalexicographic foundation. For the good of new dictionaries, the emphasis should be on the formulation of metalexicographic criteria which can be applied in any translation dictionary (bilingual or multilingual). In this regard, Wiegand's General Theory of Lexicography' can play a valuable role. For meeting the real needs as well as the reference skills of the intended target user, one also has to think about the improvement of the macro- and microstructure of existing dictionaries. And the first step to do so is the compilation of a database. Before embarking on any lexicographic activity, the lexicographer has to make sure that he or she has a representative corpus of the language which is to be described. In establishing a basis for a dictionary, one should preferably take into account all four constituents of Wiegand's general theory, namely a general section (also known as constituent theory A), an organisational section (also referred to as constituent theory B), a theory of lexicographic language research (also called constituent theory C) and a theory of lexicographic language description (also referred to as constituent theory D) (cf. Smit 1996).

For the purposes of this section, the emphasis will be on the constituent theories $\mathrm{A}, \mathrm{B}$ and $\mathrm{C}$.

As far as the constituent theory $A$ is concerned, the historical overview of Gabonese lexicography has shown that one of the shortcomings of existing dictionaries regards the theory of lexicography or metalexicography. In other words, in those dictionaries metalexicography is hardly ever represented. For the good of new lexicographic activities, lexicographers will have to decide which structure is suitable to enhance the quality of the revised as well as the new dictionaries. Which one of these structures will fit the needs as well as the reference skills of the intended target user: an integrated, a nonintegrated or a semi-integrated microstructure?

Focus on decisions regarding the necessity to include lexical items as part of main lemmata or sublemmata should also be discussed. This is relevant because all the existing dictionaries seem to show a lack of sophistication due to the absence of nested and niched lemmata. In a niching dictionary, sublemmata which do not necessarily display a semantic relation are presented in a strict alphabetical order. Furthermore this internal ordering has to be maintained with regard to the preceding and following lemmata in the vertical ordering. In a nesting dictionary two levels have also to be identified. On the internal level, sublemmata occurring within a sinuous file are not arranged strictly according to the alphabet. On the external level, the horizontal ordering does not necessarily fit into the alphabetical arrangement of the vertical ordering. The deviation on alphabetical level is not only a space-saving device but also allows the lexicographer to give an account of morphosemantic relations between sublemmata (Hausmann and Wiegand 1989: 336). 
Furthermore, as far as the dictionary articles are concerned, the average existing dictionaries only present the lemma (in the source language), morphological data, translation equivalent (in the target language) and examples. Other data categories such as indications of etymology and citations (which all existing dictionaries lack) could have improved the content of the articles of those dictionaries.

The organisational component $t^{7}$ is very important for existing as well as future dictionaries. It clearly states the mission of the dictionary project and gives a detailed discussion of all the structures involved in the preparation of a dictionary as well as an estimate of the time and capital needed for the project.

Finally, in the constituent theory $\mathrm{C}$, Wiegand distinguishes two components, namely the theory of data collection and the theory of data processing. It is a well-attested fact that the compilation of a dictionary is practically impossible without an authoritative database. In establishing a database, a balance should always be maintained between oral and written sources. For the collection of spoken language, research has to be conducted at grassroots level through fieldwork. For the sake of representativeness and for the quality of language data, field workers should be well-equipped with recording material and their set of questionnaires should cover a wide range of subjects. Once the information is captured, transcripts of conversations, dialogues or interviews have to be computerised in the form of a database or in the form of a corpus. (Cf. chapters on "Language Databases, Corpora and Other Resources" and "Dictionary Data Input" in Bureau of the WAT 1999.)

For the collection of written material it is commonly accepted that African languages do not have a strong written tradition. However, some works do exist in Gabonese languages. In this regard, Hombert and Mortiers' (1990) bibliography gives quite an impressive picture of what has been written so far in Gabonese. Those works - which cover a wide range of subjects such as religion, ethnohistory, science, oral literature and literature dealing with dictionary research - are available in the Archives Spiritaines de Chevilly-Larue (Paris), the Archives Nationales and at CICIBA, in Libreville. The language material captured on paper (cards) and/or in electronic form can be valuable sources of data for the dictionary-making process. Electronic language data makes it easier for the lexicographer to execute quick queries and searches. A database is particularly useful for the compiler when it comes to statistical matter like the creation of frequency lists. Very often the inclusion of lexical items as main lemmata or as sublemmata is determined on the basis of the usage frequency of each lexical item. Finally, the most important advantage of electronic resources is their flexibility. A wide range of dictionaries can be obtained from the same database like translation dictionaries, special-field dictionaries as well as monolingual dictionariés which all Gabonese languages lack. As far as this point is concerned and in the light of Gallardo (1980:61), one should not embark immediately on the tremendous task of compiling a comprehensive monolingual dictionary. The emphasis should first be on translation diction- 
aries designed with an appropriate structure, making it possible for the lexicographer to supply lemmata with short meaning descriptions. Then due to the flexibility of a database, the short definition can be expanded to comply with the requirements of an explanatory monolingual dictionary for example.

It is also a well-attested fact that the preparation of a database may be costly and time-consuming. Due to the fact that most existing dictionaries on Gabonese languages have been the input of single lexicographers, future lexicographic products should be the result of team efforts.

\section{Conclusion}

The lexicographic survey of Gabonese languages above shows that most of the dictionaries available for the Gabonese heritage speech forms are bilingual dictionaries and biased towards French. Another feature is that the lemmas follow a vertical alphabetically arranged order. In other words, they are straight alphabetical dictionaries and lemmata are entered according to the word tradition (only Rittaud-Hutinet (1980) presents lemmas according to the stem tradition). Some of them present interesting lexicographic features such as guiding elements (the running heads of the column), outer texts giving an account of the principle of arrangement of lemmata, the user's guidelines and a minigrammar for example. However, most of them reveal a number of shortcomings such as the absence of tones, orthographical inconsistencies as well as a lack of a metalexicographic foundation. Furthermore, as far as dictionary purposes are concerned, most earlier dictionaries were compiled to help European traders and explorers to communicate in Gabonese languages. They were also useful aids for Christian evangelisation and French colonial administration. For the good of future dictionaries, the emphasis should not only be on the structure and the quality of the lexicographic data. Future dictionaries should also be compiled for a specific target group. In other words, the genuine purposes of the dictionary should be identified and provisions to fulfil the real needs and reference skills of the intended target user should be made (cf. Wiegand 1999: 299). This can only be achieved by consistent dictionary planning taking into account both organisational and metalexicographic components. The lexicographic trend also shows an imbalance between speech forms. Some speech forms are far more developed than others. For others a lot of lexicographic work is still to be done. Therefore there is a necessity for well-trained lexicographers to bring all the Gabonese languages on par with other languages with a well-established lexicographic tradition.

\section{Notes}

1. We wish to express our profound gratitude to the Vice-Rector of Omar Bongo University, $\mathrm{Dr}$ Guillaume Moutou, the Dean of the Faculty of Arts and Human Sciences of Omar Bongo 
University, Dr J.T. Kwenzi-Mikala and Prof. James Duplessis Emejulu, Director of Grelaco for all their efforts, without which we would not have had the opportunity to be trained by the Bureau of the Woordeboek van die.Afrikaanse Taal (WAT) and to enrol as postgraduate students at the University of Stellenbosch. We must acknowledge that the original idea of this paper is from Dr J.C.M.D. du Plessis. We also want to thank Mr W.F. Botha for reading the article and making invaluable suggestions. Finally, we would like to thank Prof. R.H. Gouws, our promoter, for showing a real interest in all the lexicographic activities in which we are involved.

2. In this article we use the official Gabonese spelling and not the traditional semiphonetic spelling employed by Guthrie, Kwenzi-Mikala, and others. The underlined $\mathbf{e} \mathbf{Q}$ and $\underline{\mathbf{n}}$ represents $[\varepsilon],[0]$ and $[n]$ respectively, while $[\gamma],[[]$ and $[\beta]$ are written $g h$, sh and vh respectively. The phonetic sound [a] is represented by the symbol a in the Gabonese or thography. However, for phonological and practical reasons we have chosen to represent it by $a_{\text {, }}$ as in Make and Ghisira.

3. The names of Gabonese tribes are based on the names the speakers of these tribes used for themselves or on administrative names inherited from the colonial era. Sometimes, the latter are the product of truncation. For example: The lexical items pahouin and later pangwe are both corrupted forms of the word Fan (also written fang) by speakers of Mpongwe based on their own ethnonym Mpongwe. The process can be explained as follows: Fan > Mfan > Mpan > Mpangwe, rendered as "pahouin" by the first French transcripts around 1845 (cf. Mayer and Voltz 1990: 45). The same line of argumentation holds true for the lexical item Banzábi (speakers of Yinzebi, Nzabi and Njebi) which comes from the wrong administrative orthography Bandjabi. In fact, speakers of Yinzebi called themselves Murzębi (singular form) and Banzebi (plural form) (cf. Mayer and Voltz 1990: 44 and 51).

In addition to the foregoing, the speech forms Lindumu, Civili, Ntumu, Ghevhovhe, Ghepinzi, Yivhungu, Yilumbu, Ghisira, Lateghe Lekanini, Lembaama, Liwanzi, Ngubi, Ghalwa, Seki, Yisangu, Yitsengi, Make Yipunu, Liduma, Ikota, Ghetsogho and Mbanwe are sometimes associated with the following administrative or historical forms respectively: NDoumou (also Ndumu), Vili (also Bevili, Fiotte), Ntoumou, Pove (also Bavove, Bapowe), Apindji (Pinji, Apinji), Voungou (also Bavungu), Baloumbou (also Lumbu, Ilumbu), Eshira (also Ghisir, Sira), Teke (also Bateke), Kaningi, Obamba (also Mbede, Mbere and Mbete), Bawandji (also Wandji), Nogové (also Ngové), Galwa (also Galoua, Gallois), séki (also Sékyani, Boulou), Yisangu (also Masangu, Massango, Sangu, Shango), Yitsengi (also Tsengui, Tsangui, Tsengi), Meke (also Make, Makina), Pounou (also Pounoue or Punu), Adouma (also Aduma, Baduma), Kota (also Okota, Bakota), Tsogho (also Tsogo, Mitsogo, Getsogo) and Mbahouin (also Mbangwe) (cf. Mayer and Voltz 1990: 50-51).

4. Myene is the opening greeting formality, whereas Omyene is the name of the language.

5. Mgr. Andre Raponda-Walker was the first Gabonese priest. He is the author of books and numerous papers on Gabonese literature. For example, in "Alphabet des idiomes gabonais" (1932), he presents a set of symbols according to which the Gabonese languages should be transcribed. Attention was paid to the principle of bi-univocity: one symbol for one sound. Fifty-seven years later, in 1989, the Alphabet Scientifique des langues du Gabon (ASG) was adopted. This alphabet which serves as reference for the transeription of the Gabonese languages is based on both the International Phonetic Alphabet (IPA), revised version (Kiel 
1989) and the "Africa" Alphabet published by the International African Institute (IAI). In "Néologismes sur les idiomes gabonais" (1933) he gives an account of the history of borrowing by some Gabonese languages (e.g. Fan, Ghetsoghe, Ghisira and Civili) from Portuguese, English and French. "Dénominations astrales au Gabon" (1937) and "Enquète sur l'agriculture noire au Gabon et sur certaines techniques utilisant des produits végétaux" (1940) are terminologies or special-field dictionaries for astronomy and agriculture. The book Plantes $u t i l e s d u$ Gabon (1961) which Raponda-Walker wrote in collaboration with Sillans gives a picture of the names and uses of Gabonese plants. Some 8000 indigenous plant names, collected over a period of thirty years, as well as their scientific names and usage are listed. As far as dictionaries are concerned, Raponda-Walker is the compiler of Dictionnaire mpongrwe-français, Dictionnaire français-mpongwè, Dictionnaire getsogo-français, Dictionnaire français-getsogo and Dictionnaire etymologique des noms propres Gabonais. The variety of his publications and his vast experience on oral tradition made him the first Gabonese scientist.

6. Wiegand's contribution to the field of metalexicography covers many aspects regarding theoretical models for the compilation of both monolingual and translation dictionaries as well as the history of lexicography and dictionary use. The study of Smit (1996), which is a dictionary plan for the compilation of a special-field (i.e. music) dictionary, contains a comprehensive discussion of Wiegand's metalexicography in part 1, chapters 1 to 8.

7. We completed a training course at the Bureau of the Woordeboek van the Afrikaanse Taal (WAT) from 12 to 23 April 1999. The course covered the following themes: general and computer lexicography, and the planning and management of a lexicographic project. As a planning assignment, we compiled a framework for the revision of Raponda-Walker's Dictionnaire français-mpongwe under the guidance of Dr D.J. Van Schalkwyk, Editor-in-Chief of the Woordeboek van die Afrikaanse Taal (WAT). This modest work can be a useful tool for the revision of the proposed dictionary as soon as the project is established.

After the training at the Bureau, we also attended a series of lectures presented by Prof. R.H. Gouws in the Department of Afrikaans and Dutch at the University of Stellenbosch. During the course, the focus was on a general theory of lexicography (with special reference to Wiegand's theory). As far as dictionary typology is concerned, particular attention was given to equivalent relations in translation dictionaries.

\section{Bibliography}

Adam, J. 1954. Grammaire composée mbede-ndumu-duma. Brazzaville: Institut d'Études Centrafricaines.

Andeme Allogho, M.F. 1980. Esquisse phonologique du nzaman de Makokou. Mémoire de Licence. Libreville: Université Omar Bongo.

Biton, A. 1907. Dictionnaire français-ndumu et ndumu-français, précédé d'éléments de grammaire. Nantes: Imprimerie Bourgeois.

Biton, A. 1962. Kateçism Ndumu. Rome: Sociêté St Pierre Claver.

Biton, A. and J. Adam. 1969. Dictionnaire ndumu-mbede-français et français-ndumu-mbede. Petite fore de la région de Franceoille (Gabon). Grammaire ndumu-mbede. Archevèché de Libreville, Bar-leDuc: Imprimerie St Paul. 
Blanchon, J. 1997. Les formes nominales de citation à préfixe haut en Pounou (Bantu B43). Journal of African Languages and Linguistics 18: 129-138.

Blanchon, J. In preparation. Dictionnaire informatisé du Pounou.

Bodinga-bwa-Bodinga, S. and L.J. van der Veen. 1990. Plantes utiles des Evia. Pholia. Revue $d_{u}$ Laboratoire de Phonétique et Linguistique Africaine 8: 26-65.

Bodinga-bwa-Bodinga, S. and L.J. van der Veen. In preparation. Dictionnaire gevia-français.

Bonneau, J. 1956. Grammaire pounoue et lexique pounoue-français. Brazzaville: Institut d'Etudes Cen. trafricaines.

Bureau of the WAT. 1997-1998. Activities of the Woordeboek van die Afrikanse Taal (WAT). Stellenbosch: Bureau of the WAT.

Bureau of the WAT. 1999. Course in Computer Lexicography. Unpublished course notes.

Castex (Dr). 1938. Vocabulaire comparé des principaux dialectes ayant cours en Haut-Ogooué. Essai de classification. Bulletin de la Société des Recherces Congolaises 26: 23-54.

Dahin (R.P.). 1893. Vocabulaire franç̧ais-aduma; vocabulaire aduma-français. Kempten: Kosel.

Delorme, A. 1877. Dictionnaire français-mpongwè. Paris: Missionnaires de la Congrégation du St Esprit et du St-coeur de Marie.

Doke, C.M. and D.T. Cole. 1963. Contributions to the History of Bantu Linguistics. Johannesburg: Witwatersrand University Press.

Emejulu, J. and F. Pambo Loueya. 1990. yilumbu. Revue Gabonaise des Sciences de l'Homme 2: 197. 201.

Emejulu, J. and Y. Nzang-Bie. 1999. Linguistic Perspectives in Gabon. Colloquium, Grand Forks, Summer Institute of Linguistics, University of North Dakota, July 20, 1999.

Gachon, J.-B. 1881. Dictionnaire mpongwè-français, précédé des principes de la langue mpongwe.

Gachon, J.-B. 1891. Bible Gnango ine agamba mi re tendo pa gou'ejango j'agnambie ji felio né TESTAMAN NOUNGOU NI TESTAMAN GNONA gou'inongo gni mpongoue. Sente-Marie yi Gabon. Freiburg im Breisgau: Herber B. Libr. Edit. Pontifical.

Galley, S. 1889. Nteni osi nteni Fañwe. Talagouga: Imprimerie de la Mission.

Galley, S. 1964. Dictionnaire fang-français et français-fang, suivi d'une grammaire fang. Neuchátel: Henri Messeiller.

Gallardo, A. 1980. Dictionaries and the Standardisation Process. Zgusta, L. (Ed.). Theory and Method in Lexicography: 59-69. Columbia: Hombeam Press.

Gouws, R.H. 1996. A Sequence for Meeting Lexicographic Needs. Lexicography as a Financial Asset in a Multilingual South Africa: 97-110. Pretoria: Department of Arts, Culture, Science and Technology.

Gouws, R.H. and D.J. Prinsloo. 1998. Cross-Referencing as a Lexicographic Device. Lexikos 8: $17-$ 36.

Grimes, B.F. 1996'13. Ethnologue. Dallas: Summer Institute of Linguistics, Inc.

Guthrie, M. 1953. The Bantu Languages of Western Equatorial Africa. Oxford: Oxford University Press.

Hausmann, F.J. and H.E. Wiegand. 1989. Component Parts and Structures of General Monolingual Dictionaries: A Survey. Hausmann, F.J. et al. (Eds.). 1989-1991. Wörterbücher. Ein internationales Handbuch zur Lexikographie / Dictionaries. An International Encyclopedia of Lexicography / Dictionnaires. Encyclopédie internationale de lexicographie: 328-360. Berlin: Walter de Gruyter.

Hombert, J.M. 1990. Les langues du Gabon: Etat des connaissances. Revue Gabonaise des Sciences de l'Homme 2: 29-36. 
Hombert J. M. and A.-M. Mortier. 1990. Bibliographie des langues du Gabon. Revue Gabonaise des Sciences de l'Homme 2: 335-355. Mise à jour de la bibliographie publiée dans Pholia. Revue du Laboratoire de Phonétique et Linguistique Africaine 1. 1984.

Jacquot, A. 1978. Le Gabon. D. Barreteau. Inventaire des éludes linguisiques sur les pays d'Afrique Noire d'expression française et sur Madagascar: 493-503. Paris: CILF.

Johnston, Harry H. 1922. A Comparative Study of the Bantu and Semi-Banlu Languages. Volume II. Oxford: Clarendon Press.

Kidda Awak, Mairo. 1990. Historical Background, with Special Reference to Western Africa. Hartmann, R.R.K. (Ed.). 1990. Lexicography in Africa: 8-18. Exeter: University of Exeter Press.

Kwenzi-Mikala, J.T. 1987. Contribution à l'inventaire des parlers Bantu du Gabon. Pholia. Revue du Laboratoire de Phonétique et Linguistique Africaine 2: 103-110.

Kwenzi-Mikala, J.T. 1988. L'identification des unités-langues bantu gabonaises et leur classification interne. Muntu 8: 54-64.

Kwenzi-Mikala, J.T. 1988a. Quelques remarques sur la transcription des textes oraux en langues africaines. Pholia. Revue du Laboratoire de Phonétique et Linguistique Africaine 3: 207-211.

Kwenzi-Mikala, J.T. 1989. Contribution à l'analyse des emprunts nominaux du yipunu au français. Pholia. Revue du Laboratoire de Phonétique et Linguistique Africaine 4: 157-170.

Kwenzi-Mikala, J.T. 1990. Quel avenir pour les langues gabonaises? Revue.Gabonaise des Sciences de I'Homme 2: 121-124.

Kwenzi-Mikala, J.T. 1990a. L'anthroponymie chez les Bapunu du Sud-Gabon. Pholia. Revue du Laboratoire de Phonétique et Linguistique Africaine 5: 113-120.

Kwenzi-Mikala, J.T. 1998. Parlers du Gabon. A. Raponda-Walker: Les langues du Gabon: 217. Libreville: Editions Raponda-Walker.

Kwenzi-Mikala, J.T. 1998a. Parémies d'Afrique centrale. Libreville: Éditions Raponda-Walker.

Kwenzi-Mikala, J.T. 1998b. Localisation des parlers du Gabon. A. Raponda-Walker: Les langues du Gabon: 215-216. Libreville: Éditions Raponda-Walker.

Largeau, V. 1901. Encyclopédie Pahouine. Eléments de grammaire et dictionnaire français-pahouin. Paris: E. Leroux.

Lejeune, L. 1892. Dictionnaire français-fang ou pahouin, précédé de quelques principes grammaticaux sur cette mème langue. Paris: A. Faivre et $\mathrm{H}$. Teillard.

Marichelle, C. 1900. Dictionnaire français-vili. Loango.

Marling (R.P.). 1872. Dictionnaire fang-français. New York.

Martrou, L. 1924. Lexique fan-franfais. Paris: Procure Générale (des Pères du St Esprit) / Abbeville: Imprimerie Paillard.

Mayer, R. 1987. Langues des groupes Pygmées du Gabon: un état des lieux. Pholia. Revue du Labora. toire de Phonétique et Linguistique Africaine 2: 119-127.

Mayer, R. 1990. Histoire de l'écriture des langues du Gabon. Revue Gabonaise des Sciences de l'Homme 2: 65-91.

Mayer, R. and M. Voltz. 1990. Dénominations ethnoscientifiques des langues et des ethries du Gabon. Revue Gabonaise des Sciences de l'Homme 2: 43-53.

Mba-Nkoghe, J. 1981. Phonologie et classes nominales en fang (Langue bantoue de la zone $A$ ). Thèse $3 \mathrm{e}$ cycle. Paris: Université Sorbonne Nouvelle.

Mba-Nzue, N. 1981. Esquisse phonologique du muai (parler de Minvoul). Mémoire de Licence. Libreville: Université Omar Bongo. 
Mouguiama-Daouda, P. 1995. Les dénominations ethnoichtyologiques chez les bantous du Gabon. Thèse de doctorat. Lyons: Université Lyon 2.

Muroni, J.-M. 1989. Petit dictionnaire bantou du Gabon: français-ndjabi, ndjabi-français. Paris: L'Harmattan.

Naidaillac, L. 1992. Lexique isangu-français. Lyons: Université Lyon 2.

Naidaillac, L. In preparation. Lexique yinzebi-français.

Ondo-Mebiame, P. 1992. De la phonologie à la morphologie du fang parlè à Aboumezok (langue Bantu A. 78). 2 volumes. Thèse de doctorat. Tervuren: Université Libre de Bruxelles.

Perron, P. 1964. Lexique français-ikota. 2 volumes. Makokou: Mission Catholique.

Puech G. 1990. Bekwel. Revue Gebonaise des Sciences de l'Homme 2: 127-128.

Raponda-Walker, A. 1930-1934. Dictionnaire mpongwè-français, suivi d'eléments de grammaire. Metz: Imprimerie de la Libre Lorraine.

Raponda-Walker, A. 1932. L'alphabet des idiomes gabonais. Journal de la Société des Africanistes 3(2): 305-314.

Raponda-Walker, A. 1933. Les néologismes dans les idiomes du Gabon. Journal de la Société des Africanistes 3(2): 305-314.

Raponda-Walker, A. 1937. Denominations astrales au Gabon. Bulletin de la Societe des Recherces Congolaises 24: 150-166.

Raponda-Walker, A. 1940. Enquête sur l'agriculture noire au Gabon et sur certaines techniques utilisant des produits végétaux. Reoue de Botanique et d'Agriculture Appliquée 24: 150-166.

Raponda-Walker, A. 1961. Dictionnaire franf̧ais-mpongwè. Brazzaville: Imprimerie St Paul. 19952. Classiques Africains.

Raponda-Walker, A. s.a. Dictionnaire getsogo-français/Dictionnaire français-getsogo. Typescript.

Raponda-Walker, A. and R. Sillans. 1961. Plantes utiles: essai d'inventaire et de concordance des noms vernaculaires et scientifiques des plantes spontanees et introduites $d u$ Gabon. Paris: Lechevalier.

Rittaud-Hutinet, C. 1980. Lexique. Nsuka-Nkutsi, F. (Ed.). Eléments de description du Punu: 193-245. Lyons: PUL.

Smit, M. 1996. Wiegand's Metalexicography as a Framework for a Multilingual, Multicultural, Explanatory Music Education Dictionary for South Africa. Unpublished D.Litt. thesis. Stellenbosch: University of Stellenbosch.

Touré, A. 1990. L'écriture des langues africaines: évolution et principes méthodologiques. Revue Gabonaise des Sciences de l'Homme 2: 55-63.

Van Wyk, E.B. 1995. Linguistic Assumptions and Lexicographic Traditions in the African Languages. Lexikos 5: 82-96.

Wiegand, Herbert E. 1999. Semantics and Lexicography. Selected Studies (1976-1996). Edited by Antje Immken and Wemer Wolski. Tübingen: Max Niemeyer.

Yembi Bouka, L. 1995. Structures phonologiques et structures prosodiques (le modele bekwel). Thèse de doctorat. Tervuren: Université Libre de Bruxelles. 